\title{
THE SCIENCE AND TECHNOLOGY BILL
}

\begin{abstract}
$\mathrm{W}$ HEN the Science and Technology Bill was considered in Committee in the House of Commons on January 20, several amendments were proposed to the clause relating to the Research Councils. However, these were withdrawn on receiving satisfactory explanations from Mr. M. Stewart, then Secretary of State for Education and Science. Mr. D. Price had raised the question of the functions of these Councils and the choice of priorities in the light of the final report of the Advisory Council on Scientific Policy. Mr. Stewart agreed as to the importance of priorities in research and said that besides their responsibility for the execution of research the Research Councils were responsible for the choice of priorities within their fields. The new Council on Scientific Policy was responsible for advising the Government on the choice of priorities in the allocation of funds between the various fields represented by the Research Councils and elsewhere. Mr. Price raised a further question regarding the Natural Environment Research Council, and while he and other speakers welcomed the establishment of this Council, there was some concern as to whether its responsibilities were wide enough in regard to water. Some natural resources are the responsibility of other Ministries: gas and coal (Ministry of Power), sand and gravel (Ministry of Public Buildings and Works), etc. Mr. Stewart did not entirely dispel these fears, and admitted that soil surveys fell within the scope of the Agricultural Research Council. Oceanographic research would come within the sphere of the Natural Resources Research Council, which would take over existing interests in the National Institute of Oceanography.
\end{abstract}

A further amendment advocated the establishment of a Work Study Research Council. However, while agreeing as to the importance of this subject, Mr. Stewart deprecated any such decision pending the report of the Hey. worth Committee on the Social Sciences, which might well point to the creation of a research council for the social sciences. The question of space research and a Space Research Council wes also raised by several members in this interesting and well-informed debate, but both $\mathrm{Mr}$. Q. Hogg and Mr. Stewart, supported by other members, resisted the argument. While agreeing that space research was an essential human effort at the present time, they maintained that the size of the British effort in that field was a matter for the Council on Scientific Policy and the Government and not something to be written into the Bill.

Reference was also made to the position of the National Research Development Corporation. While the Corporation welcomed, in its annual report for 1963-64 (published a few days after the debate), the statement made by the previous Government in July that it had been decided to seek powers to extend the scope and scale of its work so that it would be able to contribute more effectively to industrial innovation and development, Mr. Stewart did not refer to the legislation then promised for this purpose, including provision for a modification and extension of the financial and other conditions under which the Corporation operates.

Sir Edward Appleton's opening address, "The Relationship between Science and Administration", in the Scottish Office Course on Science, given in Edinburgh on January 8 , provides an interesting gloss on the debate. After reviewing the development of the relations between science and Government in Britain from the formation of the Royal Society down to the establishment of the National Physical Laboratory in 1900, and the foundation of the Department of Scientific and Industrial Rsearch with its Advisory Council, Sir Edward referred to the Science and Technology Bill. He referred also to the Haldane Report on the machinery of government and particularly its doctrine that research and enquiry should be carried out under a Minister without specific departmental duties, although in close touch with Departments concerned with the activities under investigation. Sir Edward commented that thirty years ago potential user departments were often not well qualified to appreciate when scientific advice could be helpful, nor to estimate its value when given. It would seem that even to-day he has misgivings about the Road Research Laboratory being transferred to the Ministry of Transport. He is also uneasy as to the implications of appointing personal scientific advisers to a Minister, believing that this device contributed to difficulties during the War. It is not clear whether or not this criticism relates to the growing practice of appointing chief scientific officers of high status in Ministries concerned with scientific and technical matters.

\section{NORTH SEA LICENCES FOR THE GAS COUNCIL-AMOCO GROUP}

\begin{abstract}
7 HE Gas Council-Amoco Group comprises the Gas Council, Amoco U.K. Petroleum Ltd. (a subsidiary of American International Oil Company), Amerada Exploration Ltd. (a subsidiary of Amerada Petroleum Corporation), and Texas Eastern (U.K.) Ltd., all British corporations, and was formed early in 1963. According to a report issued on behalf of the Group (P.R. 6685, September 1964, The Gas Council, 1, Grosvenor Place, London, S.W.1), five licences to drill for oil and natural gas in the North Sea have been granted to the Group, which has already completed extensive seismic survey work within its now designated area of 3,600 square miles of sea; this area is divided into 36 blocks, with loci scattered over an area ranging from Peterhead in the north of Scotland down to offshore of the Norfolk coast.

Production licences cost $£ 6,250$ per block for an initial period of six years, with an option for a further 40 years "... on no more than half the area awarded to the Group at annual sums rising from $£ 10,000$ to $£ 72,500$ per block".
\end{abstract}

It is anticipated that drilling operations will begin in 1965. In this connexion it has recently been reported in the national Press that the Group has placed an order with John Brown and Co., Ltd., of Glasgow, worth $£ 2.5$ million, for a drilling platform, to operate in the North Sea area. The published particulars of this particular platform are impressive. It will stand on latticed steel legs $387 \mathrm{ft}$. high and will be built to accom. modate 50 operatives; it will include a helicopter deck to facilitate communications with on-shore bases; it is designed to withstand winds of $115 \mathrm{~m} . \mathrm{p} . \mathrm{h}$. and waves of $64 \mathrm{ft}$. These factors put this project in the class of super drilling platforms, one of the largest and most expensive structures so far conceived for offshore drilling for oil and gas. According to the report from the Group, it is considered unlikely that the rig, when in operation, will be able to drill more than two or three wells a year, because it is anticipated that completion depth could, at any one site, range to the $10,000 \mathrm{ft}$. mark, or even deeper. 
A majority of the world's great oil and gas fields have been proved only after drilling several dry holes and expending large amounts of money; even a single field may require several holes to be drilled before it is proved a commercial proposition. The hazards of offshore drilling, where there is known continuity of seaward extension of land-based oilfields, are often formidable; in the case of the North Sea, the hazards, and consequently the risk of failure, are greatly increased because of lack of such continuity. The North Sea, at least in so far as British licences at present extend, is a relatively unknown environment so far as oil and gas potentialities are concerned; to this extent optimism for the outcome, not only of the Gas Council-Amoco Group's enterprise, but equally for the pioneer efforts of other major oil interests now actively engaged in the search, must necessarily bo tempered with caution and restraint; this is implicit in the report herein considered.

\section{ELECTRON MICROSCOPY OF GRAPHITIC CRYSTALLITES IN Meta-ANTHRACITE}

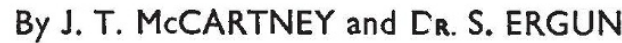

Pittsburgh Coal Research Center, Bureau of Mines, U.S. Department of the Interior, Pittsburgh, Pa.

$\mathrm{E}^{\mathrm{L}}$

LECTRON microscopy of coals and coal components has been greatly facilitated by development of a technique for cutting ultra-thin sections (500-2000 $\AA$ ) of these materials by microtomy with a diamond knife ${ }^{1-5}$. Granular structures as small as $100 \AA$ and pores of the order of 20-50 $\AA$ have been reportedly observed in some of these investigations. Results of recent investigations of various coal components have been described elsewhere ${ }^{6}$.

Of special interest among these were observations of an apparent vitrain band in a meta-anthracite from Leoben, Austria. Fig. 1 shows a typical electron micrograph of an ultra-thin section of this material. Although these sections appeared to be continuous, the micrograph reveals a jumble of thin platelets interspersed with many holes. Many of the platelets are nearly parallel to the plane of the micrograph, and their oval or polygonal outlines can be traced. Some have a roughly hexagonal shape. Both X-ray and electron diffraction patterns of this material have shown most of the characteristic sharp lines of graphite ${ }^{7,8}$. The latter pattern is shown in Fig. 2. The rings, in order from the centre, are identifiable with the following reflexions of graphite: (002), (100-101 doublet), (004), (103) (weak), (110), (112), (201), (114), (121), (300), and (220). Estimations of crystallite size from measurements of line broadening in the X-ray patterns have yielded a value of $800 \AA$ for this coal.

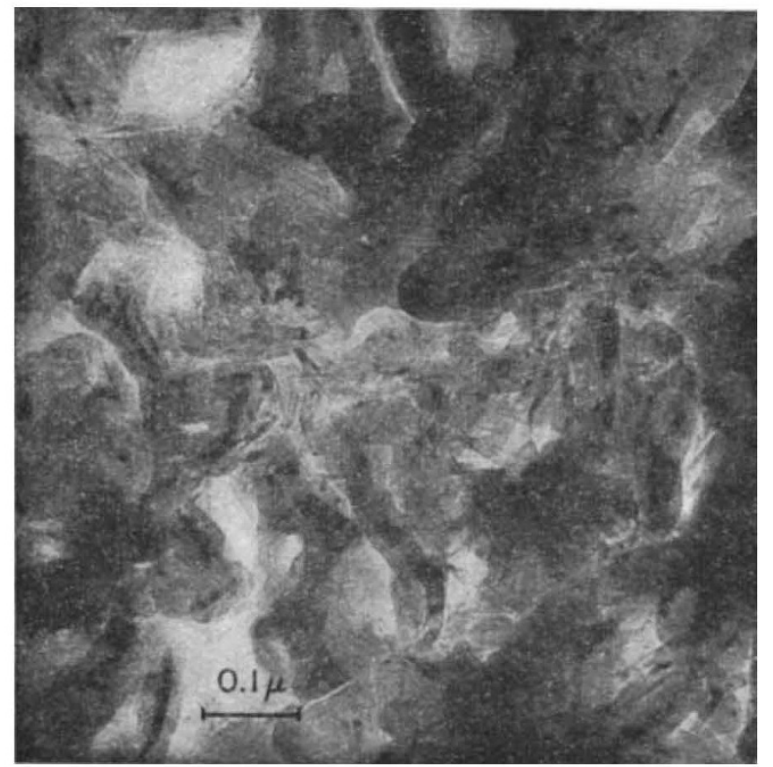

Fig. 1. Electron micrograph of an ultra-thin section of an apparent vitrain band in a meta-anthracite from Leoben, Austria. ( $(\times 93,750$.
Measurements of diameters of about a dozen clearly defined platelets in electron micrographs resulted in an average diameter of about $800 \AA$. It is evident that the platelets are crystallites of graphite that have formed and grown from aromatic layer clusters during metamorphosis of this meta-anthracite.

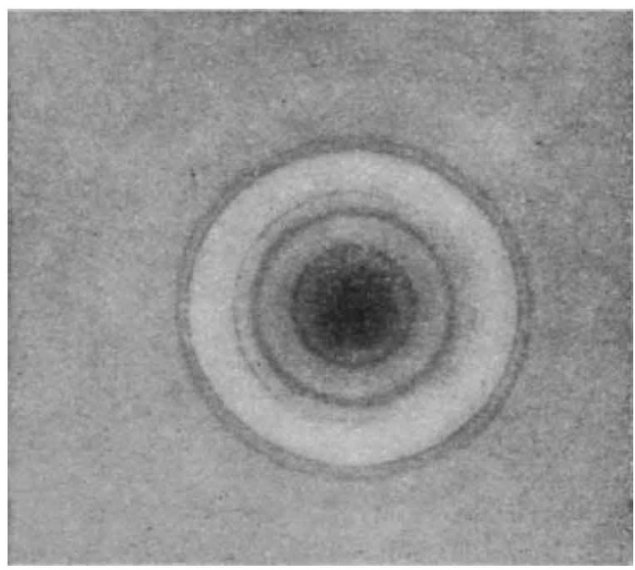

Fig, 2. Electron diffraction pattern of the section of Fig. 1

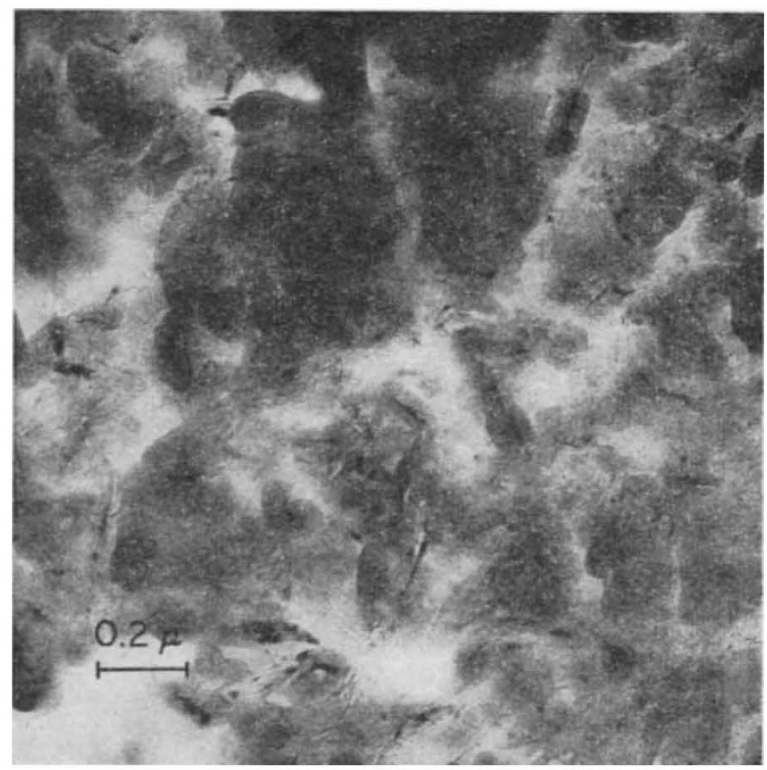

Fig. 3. Electron micrograph of a section of Leoben meta-anthracite cut parallel to the bedding. $(\times 45,000)$ 